\title{
Fluid Volume
}

National Cancer Institute

\section{Source}

National Cancer Institute. Fluid Volume. NCI Thesaurus. Code C124480.

The amount of three dimensional space occupied by a fluid. 